\title{
Similarities and Differences between River Buffaloes and Cattle: Health, Physiological, Behavioral and Productivity Aspects
}

\author{
Aldo Bertoni ${ }^{1}$, Fabio Napolitano ${ }^{2}$, Daniel Mota-Rojas ${ }^{3, *}$, Emilio Sabia $^{4}$, \\ Adolfo Álvarez-Macías ${ }^{3}$, Patricia Mora-Medina ${ }^{5}$, Armando Morales-Canela ${ }^{6}$, \\ Jesús Berdugo-Gutiérrez ${ }^{7}$ and Isabel Guerrero- Legarreta ${ }^{8,{ }^{*}}$
}

\author{
${ }^{1}$ Master's Program in Agricultural and Livestock Sciences [Maestría en Ciencias Agropecuarias], Universidad \\ Autónoma Metropolitana (UAM), Xochimilco Campus, 04960, Mexico City, Mexico \\ ${ }^{2}$ Scuola di Scienze Agrarie, Forestali, Alimentari ed Ambientali, Università degli Studi della Basilicata, 85100, \\ Potenza, Italy \\ ${ }^{3}$ Neurophysiology, Behavior, and Animal Welfare Assessment, Department of Animal Production and \\ Agriculture (DPAA), Universidad Autónoma Metropolitana (UAM) Xochimilco Campus, 04960, Mexico City, \\ Mexico \\ ${ }^{4}$ Faculty of Science and Technology, Free University of Bozen, 39100, Bolzano, Italy \\ ${ }^{5}$ Livestock Science Department, Universidad Nacional Autónoma de México (UNAM), Facultad de Estudios \\ Superiores Cuautitlán, 54714, State of Mexico \\ ${ }^{6}$ Ciencias Agrícolas, Universidad EARTH, Guácimo, 70602, Costa Rica \\ ${ }^{7}$ Latin American Center for the Study of Buffalo, Colombia, National University of Colombia, Bogotá, 111321. \\ Colombia \\ ${ }^{8}$ Department of Biotechnology Food Science, Universidad Autónoma Metropolitana-Iztapalapa, (UAM-I), \\ 09340, Mexico City, Mexico
}

\begin{abstract}
The river buffalo is an emerging production species worldwide; indeed, it is overtaking other cattle as a producer of meat and milk in some countries. Though both species belong to the Bovidae family, they show significant anatomical, physiological, and behavioral differences due to their different phylogenetic positions. The river buffalo is a rustic animal that can benefit from low-quality, fibrous forages due to its digestive system, in contrast to beef cattle or dairy cows. Besides, the buffalo cow's reproductive apparatus has fewer cervical muscle rings and a shorter vagina and cervix. This species has maintained its seasonal breeding pattern, also in contrast to Bos indicus and Bos taurus. Even though buffaloes have an inefficient thermoregulating system, scarce hair, and a thicker epidermis, they are more resistant to tropical weather conditions if water for wallowing is available than dairy cows, which in turn adapt better to temperate zones. Due to the morphology of the river buffalo's mammary glands, they produce less milk, while their conical teats with narrower sphincters decrease predisposition to mastitis compared to dairy cows. Thus, the study of the anatomical and physiological differences among river buffalo, Bos Taurus, and Bos Indicus will allow the implementation of strategies to improve the former's productivity while also increasing welfare levels according to the production system in which they are raised.
\end{abstract}

Keywords: Behavior, buffalo production, buffalo disease, cattle, river buffalo, dairy.

\section{INTRODUCTION}

In recent years, the river buffalo (Bubalus bubalis) has emerged as a species with a promising future as an alternative economic activity and, more importantly, a source of food for human consumption [1]. Due to this surge, it has rapidly replaced other bovines (dairy and beef cattle) in production units due to its following capacities,

*Address correspondence to these authors at the Neurophysiology, Behavior and Animal Welfare Assessment, Universidad Autónoma Metropolitana (UAM), Calzada del Hueso 1100, Del, Coyoacan, 04960, Mexico City, Mexico;

E-mail:dmota@correo.xoc.uam.mx

Department of Biotechnology Food Science, Universidad Autónoma Metropolitana-Iztapalapa, (UAM-I), 09340, Mexico City, Mexico;

E-mail: isabel_guerrero_legarreta@yahoo.com
- to adapt complex habitats (river buffalo welfare),

- $\quad$ an excellent human-animal relationship [2-4],

- its reproductive and productive performance, which led to an expansion of herds [5-11].

River buffaloes are raised primarily in humid tropical regions. They now offer cattle-breeders an option for diversifying ranching species thanks to its capacity to adapt to environments where soils with deficient drainage predominate $[12,13]$. This species has also shown the ability to efficiently utilize both natural and induced pastures generally of low-to-medium quality [14-16]). Given these conditions, the river buffalo has been raised for two, or even three, purposes, namely, 
milk and meat production, and as a draft animal, with some breeds traditionally used for the production of mozzarella cheese. According to data from the United States Department of Agriculture (USDA), global production of fluid milk in 2018 was 605.8 million tons (MDT); $83.4 \%$ of this volume corresponded to cow's milk, the rest from other species, with the river buffalo contributing $13 \%$ [17].

Regarding milk production, buffalo cows in Italy lactate for an average of 270 days, generating 2,462 $\mathrm{kg} / \mathrm{lactation}$ with $8.07 \%$ and $4.65 \%$ of fat and proteins, respectively. In comparison, Holstein dairy cows have an average production of $9,690 \mathrm{~kg} / \mathrm{lactation}$ with $3.77 \%$ of fat and $3.37 \%$ of protein. This indicates that buffalo cow milk has a high compositional value, while dairy cows produce more significant quantities [18]. Recent studies have also evaluated the physicochemical and quality properties of buffalo meat, and value-added products made with it (e.g., hamburgers and breaded meats, among others) that compete for consumer preferences with cattle-based products. In this context, though dairy cows, beef cattle and buffaloes all produce meat and milk, and are members of the Bovidae family, they present significant phylogenetical, morphological, and behavioral differences. The objective of this paper is to elucidate and analyze the anatomical and physiological characteristics and production systems of buffalo cows and compare them to those of cattle to identify key differences and similarities among these animals. Besides, this review seeks to verify the knowledge required to avoid mistakes when breeding buffaloes or adapting them to different production systems that could compromise their welfare and, as a consequence, undermine the productive and reproductive performance on which the profitability of dairy buffalo production units depends.

\section{ANATOMY AND PHYSIOLOGY}

Like dairy cows and beef cattle, river buffaloes belong to the Bovidae family. However, they occupy distinct phylogenetic positions and show anatomical, physiological, and behavioral differences due to their different karyotypes $[19,20]$. They are incompatible for cross-breeding because the river buffalo belongs to the Bubalinae sub-family, while cattle belong to the Bovinae sub-family [21]. The main anatomicalphysiological differences are found in the digestive tract, reproductive apparatus, thermoregulating system, mammary gland, and hooves [15] (Figure 1), which are associated with differences in productive and reproductive performances [22]. In the following sections, the most important morphophysiological and reproductive aspects that distinguish the river buffalo from dairy cows and beef cattle are described at length. See Figure 1 [1, 15, 21-35].

\section{Digestive System}

The digestive system of ruminants comprises several compartments -rumen, reticulum, omasum, abomasum - that allow these animals to hydrolyze and

Better use of medium and low quality fodder. Puppo and

Lower prevalence of methane-generating bacteria in rumen. Ranjhan, [30].

Better feed conversion rates. Fundora et al.

[31].

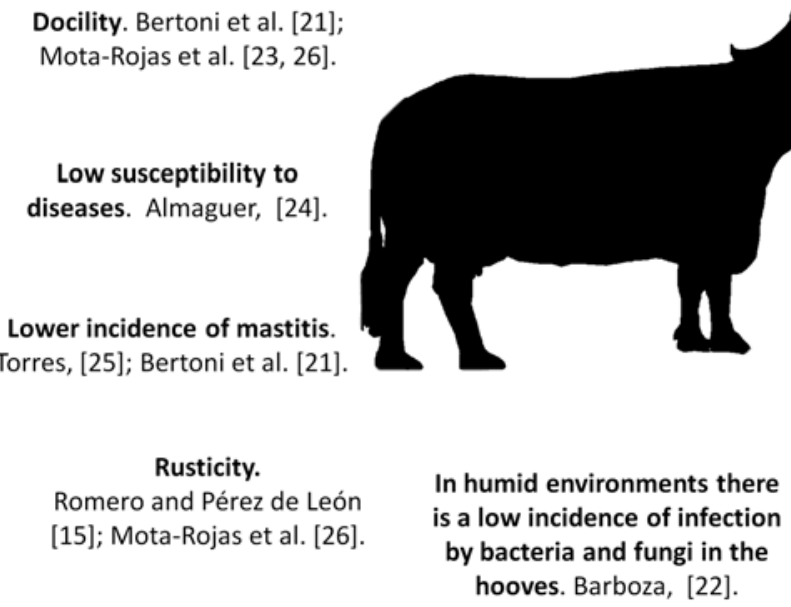

Production of $A 2$ milk and high compositional quality. El-Salam and El-Shibiny [32]; Riaño and Narváez, [33].

Meat with less cholesterol and more fatty acids w-6 and w-3. Neath et al. [34]; Kandeepan et al. [35]; Guerrero-Legarreta, et al. [1]. bacteria and fungi in the 
Table 1: Differences in the Digestive Systems of River Buffaloes and Cattle

\begin{tabular}{|c|c|c|c|}
\hline Indicators & River buffalo & Cattle & Authors \\
\hline \hline Rumen-reticulum $(\mathrm{kg})$ & 7.38 & $4.96-5.72$ & Leao et al. [38] \\
\hline Rate of passage through the rumen-reticulum(h) & 40.65 & 33.44 & Bartocci et al. [39] \\
\hline Average retention time in the gastrointestinal tract (h) & 57.73 & 64.55 & Bartocci et al. [39] \\
\hline Volatile fatty acids in rumen liquid (meq / 100ml) & $5.3-11.2$ & $4.8-10.4$ & Angulo et al. [36] \\
\hline Methane producing bacteria (\%) & 10 & 20 & Mendes and Lima, [13] \\
\hline
\end{tabular}

ferment the fibrous portion of the walls of the cells of forage plants. Though both buffalo and dairy cows are considered large ruminants [36]), river buffaloes present differences in their digestive system, such as longer length and higher capacity of the gastrointestinal tract, faster tract passage, more excellent digestion, and ruminal contractions, and microbiota with distinct characteristics (populations of microorganism, $\mathrm{pH}$, protein synthesis), among others $[13,37]$. These differences explain why river buffaloes can efficiently utilize the nutrients in food, especially in production systems where forages of low-to-medium quality predominate.

Studies by Leao et al. [38] that compared the digestive tracts of buffaloes with domestic cattle found that the former had higher food storage capacity because the rumen-reticulum complex is significantly larger (Table 1). A study of adult animals demonstrated that the mean rate of food retention in domestic cattle is slower than in the river buffalo. However, the latter retained food in the rumen-reticulum complex for more time [39]. Several authors have attributed the recent result to more efficient mastication and, consequently, more significant degradation of the fibrous fraction in the rumen [27-29]. Similarly, Sideney and Lyford [40] observed more developed rumen papillae in the buffalo, along with increased absorption of fermentation products [36].

Likewise, the rumen of dairy buffaloes and dairy cows present a diverse population of microorganisms that confer the ability to unfold the Beta linkages of the structural carbohydrates present in pasture [36]). Compared to the cow's rumen, the buffalo presents larger populations of cellulolytic, proteolytic, amylolytic, and lipolytic bacteria and fungi under identical dietary conditions [29, 37, 41, 42]. This enables the buffalo's rumen to degrade the cell walls of forages and the proteins in its diet more efficiently, thus achieving a higher rate of transformation of low-quality forage into volatile fatty acids (VFA) ammonia [30, 43, 44]. A characteristic associated with greenhouse gas production that favors the river buffalo is the prevalence of gas-producing bacteria, which is lower in this species $(10 \%)$ than in dairy cows or beef cattle $(20 \%)$. It is estimated that buffaloes produce smaller amounts of methane [13], which can be of value in controlling greenhouse gas emissions.

Regarding the reproductive apparatus of buffalo versus dairy cows, the organs are similar, but the latter's tract has less rigidity, is less muscular and slightly larger and heavier than the tract of buffalo cows $[45,46]$. This may explain the high rate of uterine prolapses observed in dairy buffaloes [47]). In a study comparing the biometry of the reproductive apparatus, the weight of the ovaries, the length and width of the right ovary, the number of cervical muscle rings, and the length of the vagina and cervix were all greater in bovines than in Murrah buffaloes, whereas the thickness of the ovaries, the length of the left oviduct, the uterine corpus, and the length and amplitude of the left uterine horn were all higher in buffaloes than in bovines. Carvalho et al. [48] did not find differences between the length and width of the left ovary, the length of the right oviduct, or the length and width of the right uterine horn between these species [48].

\section{Breeding Seasonality}

Several factors influence breeding activity, including ecological and weather conditions, as these are closely related to the availability of food and the resulting reproductive efficiency. In this context, it is important to mention that dairy cows have been raised in zones using intensive production systems where higherquality food is offered year-round [49]. The breeding seasonality of dairy cows has been influenced and has been seen to decrease, due to the domestication process and the physical-biotic factors that exert effects on this species. However, in some wild animals, as well as in buffaloes and conventional cattle bred in open pasture systems, breeding seasonality continues 


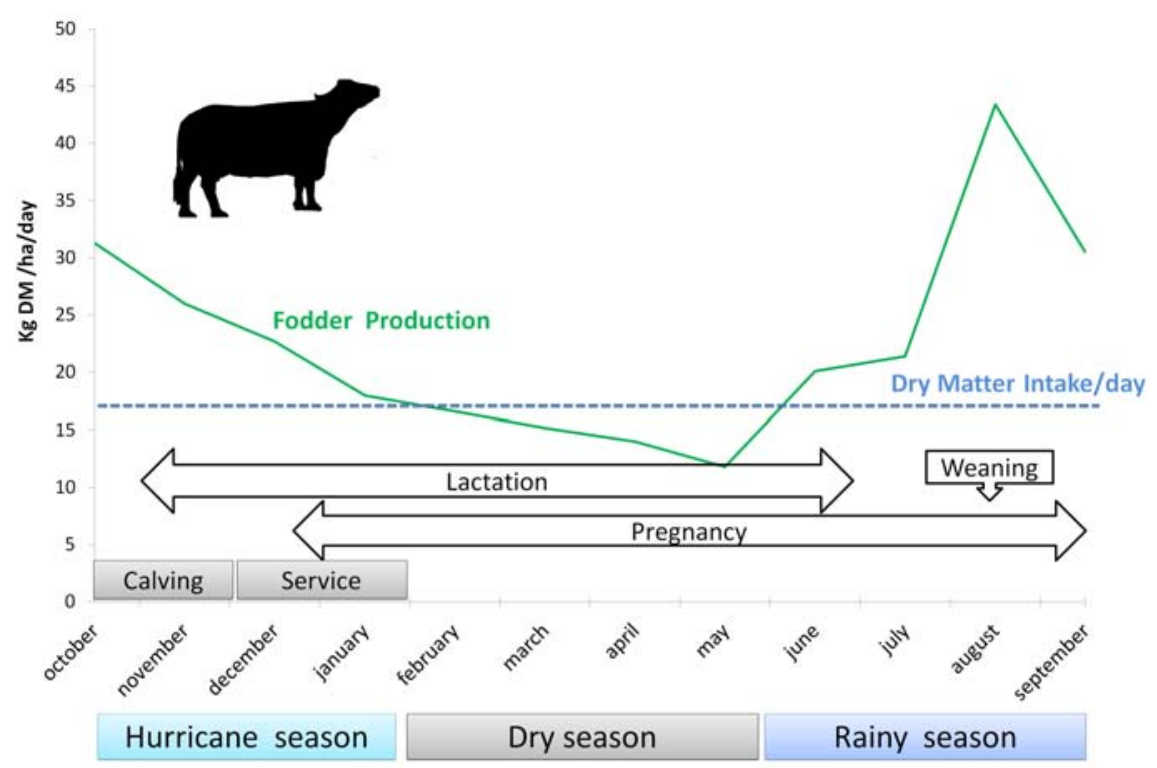

Figure 2: The river buffalo's reproductive cycle and development curve of forages in humid tropical areas of the northern hemisphere. Source: Muñoz-González et al. [51].

to be related to daylight hours and the availability of forage [16, 49] (Figure 2). River buffaloes adapt to environments with limited variation in heat and humidity, but when raised in zones far from the Equator with greater thermal and photoperiod variation during the year, their reproductive behavior becomes more varied. In fact, this species has been defined as seasonally polyestrous, with more evident manifestations of estrous in the autumn [16], the season with greater forage availability in tropical areas [50]. See Figure 2 [51].

The periods in which buffalo cows require maximum nutrition (onset of lactation and service) coincide conveniently with the normal growth curve of forage [21] (Figure 2). In the hemisphere north of the Equator, the availability of forage biomass increases as daylight time decreases; consequently, buffalo cows are seasonally polyestrous, short-day breeders, with higher manifestations of estrus in the autumn [16]). The importance of the duration of daylight in seasonal reproduction is well-documented. Melatonin acts on the pineal gland by disinhibiting active secretion of the luteinizing hormone (LH) that, together with the folliclestimulating hormone (FSH), controls estradiol secretion. However, increased daylight time augments the hypothalamus's sensitivity, generating a feedback mechanism that lowers the release of $\mathrm{LH}$. This means that there is insufficient estradiol to stimulate ovulation in mammals $[16,52,53]$.

In contrast, dairy cows do not present seasonal reproduction because they have been bred under different handling systems with levels of production that guarantee forage availability year-round. Meanwhile, dairy buffalo cows have maintained their pattern of seasonal reproduction even when they are bred in more intensive systems in which forage is readily available [49].

In the northern hemisphere, the optimal mating/service season runs from December-toFebruary with births occurring between October and December, followed by weaning in August or September. The two periods of most significant imbalance occur during the mid-term of gestation and lactation. It is important to note that the signs of estrous in buffalo cows are less evident than in domestic cattle, which presents breeders with a challenge. According to Gómez et al. [54], buffalo calves have a mean birth weight of $32-35 \mathrm{Kg}$ with no difference between the sexes, while Martínez et al. [55] reported that an average male calf weighs $36.86 \pm 3.1 \mathrm{Kg}$. After birth, young buffaloes usually have their navels disinfected to prevent pathologies like omphalitis and omphalophlebitis, after which they should be fed by the mother within 4-6 hours to allow colostrum intake. In the event that a dam rejects her calf, it is necessary to recur to nursing since one buffalo cow can nourish up to four calves at a time.

Various authors have suggested that weaning is effectuated after 6-8 months [55]. A higher value (260 $\mathrm{Kg}$ ) was reported by Bavera [56]), while Martínez et al. [55]) observed lower weights $(130-154 \mathrm{Kg})$. Clearly, 
this evidence reflects marked differences, likely related to food availability in different study areas [55], the amount and compositional quality of buffalo milk, and its effect on the weight of calves at weaning [54].

Regarding animals selected for meat production, some authors report marked weight gains. For example, Fundora [44] compared the growth of buffalypsoes and zebu cattle under the same feeding and pasture conditions during a 287-day experiment. They reported weight gain 1.6 times greater for the river buffaloes compared to the zebus. In a study conducted on buffaloes with an initial weight of 130.5 $\mathrm{kg}$ that was fed poor-quality forage, the daily weight gain measured was above $0.7 \mathrm{Kg}$, and those animals reached the slaughtering weight of $475 \mathrm{Kg}$ at 23.1 months of age [31]. Bavera [56], meanwhile, reported weights as high as $550 \mathrm{~kg}$ at 24 months of age. The incanal yield said, however, was only $54 \%$ because of the high combined weight of the animal's hide, head, and viscera [25].

Concerning buffalo cows used for milk production, studies have found markedly variable values for the age of the onset of puberty that range from 18-46 months [57]. Under favorable conditions in terms of the season of birth (i.e., if born in summertime), river buffaloes may reach puberty at between 15 and 18 months, while winter buffaloes may do so between 21 and 24 months because, though sufficiently grown at 15-18 months, they would be outside the breeding season [58]. According to Saini et al. [59], female Murrah buffaloes reach puberty at 36.5 months and a live weight of $355.8 \mathrm{Kg}$, but that under improved conditions of heat dissipation the age at first estrous could decrease to 33.1 months at a mean weight of $322.3 \mathrm{Kg}$.

The age at first service depends on when the animal reaches sexual maturity; that is when the female is capable of bringing gestation to term and raising her young. This may occur when $65 \%$ of the adult weight is reached. According to Crudeli [52], Nelore buffalo cows in Latin America with an average adult weight of $525 \mathrm{Kg}$ should have their first service at around $340 \mathrm{Kg}$. The age at first service reported by Bedoya et al. [60] was $27.27 \pm 1.97$ months. It is important to evaluate the female's corporal condition at the moment of service since, for these animals to achieve the maximum reproductive performance, they must present a corporal condition rated at 3.5-4 and 33.5 (1-5 scale) at birth and first service, respectively
[61]. With a corporal condition of 3.5, pregnancy rates as high as $86 \% \%$ have been obtained [16].

The gestation period in buffalo cows is almost one month longer than in domestic cattle, ranging from 299340 days [52], with variation by breed: Murrah, 300-306 days; the Mediterranean, 311-315 days; Jafarabadis 330 days; and March buffaloes (Carabao) up to 340 days [16]. This is another property of the buffalo that generates advantages over other species, especially domestic cattle. Finally, about management, Di Palo et al. [62] suggest that the availability of wetlands, swamps, or watering holes may increase the fertility of buffalo cows under conditions of high temperature and humidity by mitigating heat stress [62].

The lactation stage begins after calving, with an average duration of $240-270$ days [12]. According to Crudeli [52], studies in Brazil have recorded up to $5,200 \mathrm{Kg}$ of milk per lactation, though under tropical conditions, lower productions are common. The onset of lactation is accompanied by a series of physiological modifications in the buffalo cow's uterus as she recovers from the pregnancy. These changes also prepare her for her next gestation. Studies of this process (puerperium) indicate that uterine involution ends around 18 days postpartum and that the female will experience her first estrous and ovulation on days 37 and 38 postpartum, respectively [16]. Due to the duration of gestation, it is vital to ensure that the time between calving and the subsequent conception does not exceed 60 days, so the ideal interval between parturitions is close to 12 months, but under normal commercial conditions the inter-calving interval should not exceed 13-14 months, and the corresponding conception should occur between days 85-115 postpartum [16]. Martínez et al. [55] found a betweencalving interval of $13.93 \pm 1.18$ months, while Bedoya et al. [60] reported a similar figure of $13.83 \pm 1.04$ months. The reproductive aspect is of great economic importance because it affects the generational interval that translates into producing more animals in less time and, therefore, higher indices of productivity and profitability.

A direct exploration study conducted in buffalo production units in southeastern Mexico reported weaning ages of nine months at average weights of $245 \mathrm{~kg}$. The onset of puberty was recorded at 15 months at a mean weight of $300 \mathrm{~kg}$, while the first service took place at 23 months and an approximate weight of $360 \mathrm{~kg}$. Gestation was about 300 days, with the animals reaching a weight of $520 \mathrm{~kg}$ at first calving 


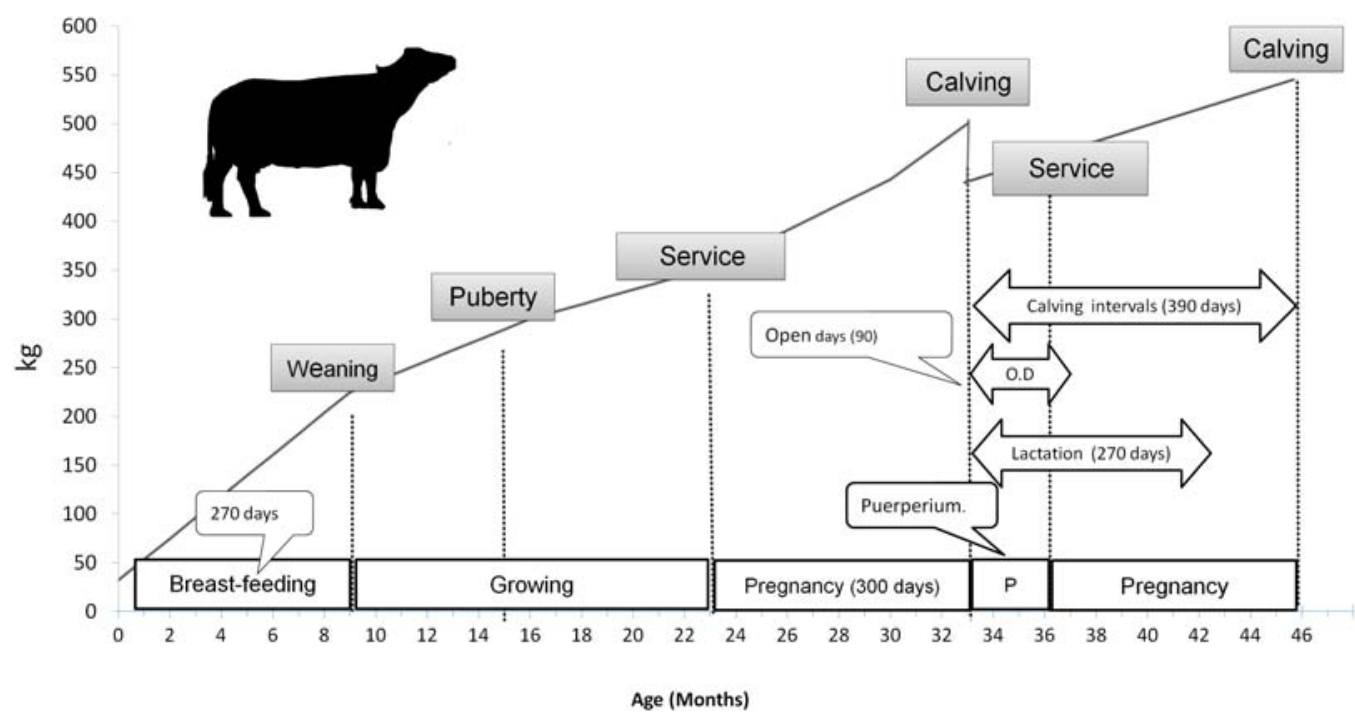

Figure 3: Productive and reproductive cycles of the female river buffalo in southeastern Mexico.

at the age of 33 months. Lactation lasted an average of 270 days, the calving/pregnancy interval was three months, and the calving interval was 390 days (Figure 3).

\section{Thermoregulation}

As endothermic animals, buffaloes and cattle are capable of controlling their body temperature by regulating their basal metabolic rate through the mechanism of thermoregulation in which the energy produced by cellular metabolism (catabolism, anabolism) can be partially dissipated by irradiating heat by the organism itself $[23,63]$. However, if heat loss is deficient, the animal can suffer heat stress. It is well-known that feedlot cattle are highly sensitive to heat stress because they consume a high-energy diet [64] and are raised in environments that lack adequate shade. Dairy cattle have been bred primarily in temperate zones, but in environmental conditions in the tropics, they are exposed to stressful climatic conditions that compromise both their productivity and welfare. For this reason, cross-breeding is common between Bos taurus and Bos indicus to decrease the metabolic rate, foster heat loss by sweating and increase tolerance for ambient heat. However, this comes with a lower efficiency in milk production [65]. In contrast, river buffaloes raised in tropical regions have an inefficient thermoregulating system under extreme heat conditions. Though this is similar to dairy and feedlot cattle (Bos Taurus), the buffalo possesses certain advantages: scarcer hair and a thicker layer of surface skin (epidermis) with a high quantity of melanin that absorbs heat and gives the characteristic black coloration [66]. Melanin particles trap ultraviolet rays (UV) to prevent them from penetrating the dermis into internal tissue layers, while simultaneously blocking solar radiation from reaching the core of the animal's body. UV rays are abundant in the solar radiation of tropical and sub-tropical regions, so excessive exposure of the skin can be harmful [23, 66-68]. Another advantageous characteristic of the buffalo is the number of hair follicles: only $135-145 / \mathrm{cm}^{2}$ compared to $3,000 / \mathrm{cm}^{2}$ in normal zebus-Bos indicus cattle. This feature exerts a double effect on river buffaloes: first, it facilitates heat dissipation; second, it exposes more skin to the direct action of solar radiation [49]. Buffaloes also have a lower density of sweat glands (168 vs. 1680 glands $/ \mathrm{cm}^{2}$ ), though theirs are commonly larger than in cattle and provide greater thermoregulation capacity $[16,49]$. These traits explain why buffaloes require shade, flood zones, and wetlands as additional preferential mechanisms of thermoregulation (Figure 4). The body heat of buffaloes in environments with high temperatures can only be kept normal if the animals have shade, ponds, swamps or mud available, or frequent application of water, preferably with a wind current for drying [68], it dissipates body heat, and maintain comfort levels [23]. See Figure 4 [69, 70].

\section{Mammary Gland}

Concerning dairy production, there are anatomicalphysiological differences between buffalo and dairy cows. However, mammary glands of both species reside in the inguinal region and consist of four quarters that are close to one another and form an 

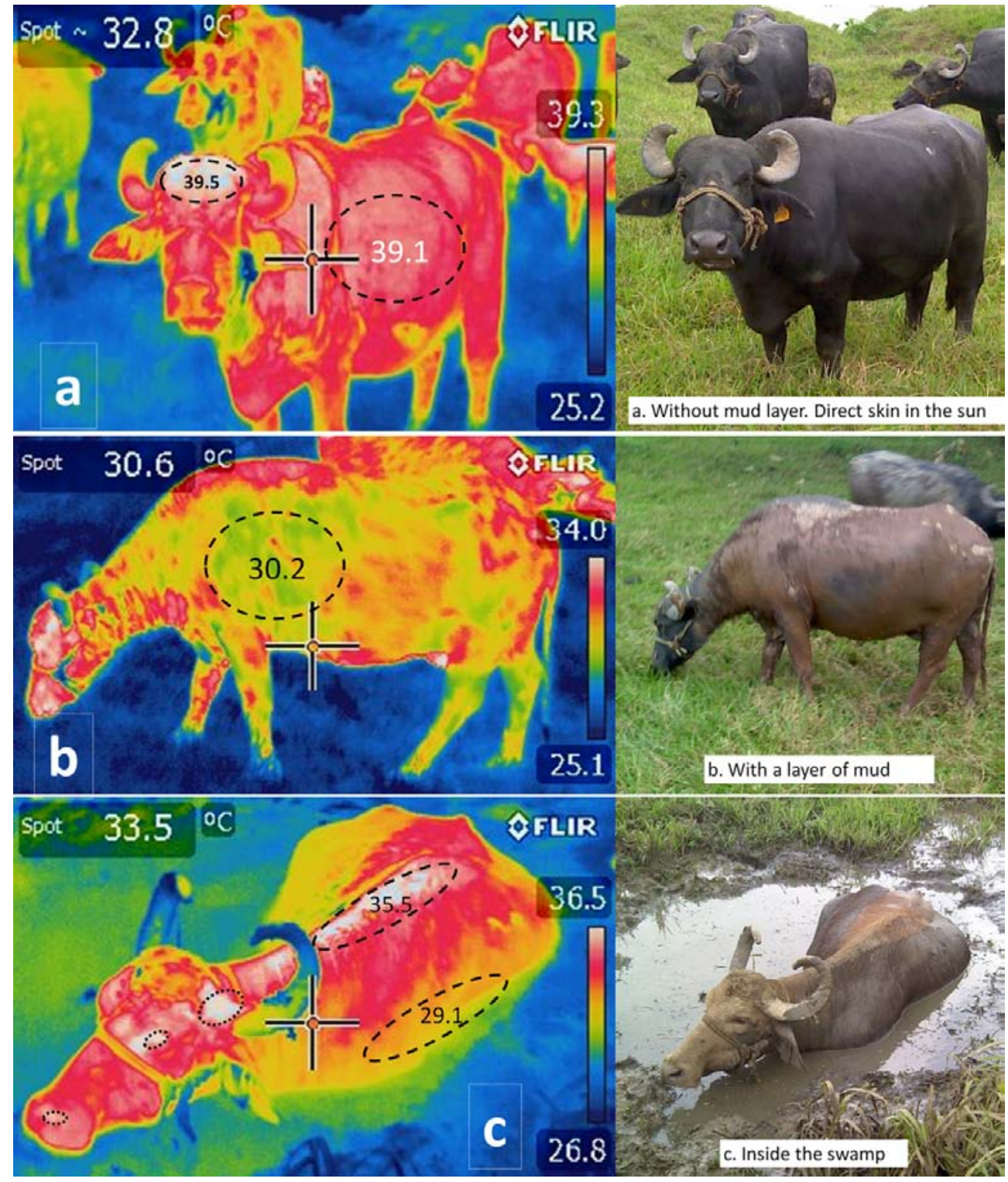

Figure 4: The effect of heat dissipation in swampy areas can be appreciated using infrared thermography. The puddled water in the swamp and the dry mud help buffaloes lower their body temperature by approximately $6^{\circ} \mathrm{C}$, as shown in these thermograms and digital photographs. a. River buffalo exposed directly to the sun in a tropical region. The surface temperature exceeds $39^{\circ} \mathrm{C}$, over $95 \%$ of the body surface (red). b. Buffalo with mud on $85 \%$ of its body. An average surface temperature of $30.2^{\circ} \mathrm{C}$ is seen in yellow. The areas without mud are visible in red color. c. A buffalo inside the swamp area. Its surface temperature in the yellow regions drops to an average of $29.1^{\circ} \mathrm{C}$. Infrared thermography is a technique used in both veterinary and human medicine to quantify the surface temperature of the skin through visualizations of thermographic changes [69, 70$]$.

udder [71]. The cistern, located in the ventral part of the gland, functions as a milk storage area that allows the synthetization of diverse quantities of milk depending on its size [71]. The udder of buffalo cow can store 92$95 \%$ of the milk in the alveolar compartment, the rest (around $5 \%$ ) is stored in the cistern. Dairy cows, in contrast, store $20 \%$ of their milk in the cistern. The fraction of cisternal milk is available for either milking or nursing the calf before the myoepithelial cells contract in response to the oxytocin that triggers milk ejection $[72,73]$. Alveolar milk, however, is available only if it is ejected actively [73]. Unlike buffalo cows, dairy cows have shown more significant development of the udder such that they can synthetize more massive amounts of milk. In addition, they have highly-elastic connective tissue that runs from the abdominal tunic -known as the suspensory system- and allows these cows to store the milk produced by the mammary glands [71]. Meanwhile, dairy buffalo cows are characterized by lower milk production and a less-developed suspensory ligament than dairy cows (Figure 5).

According to Espinosa et al. [74], a related aspect is the morpho-biometry of the teats. Those authors 


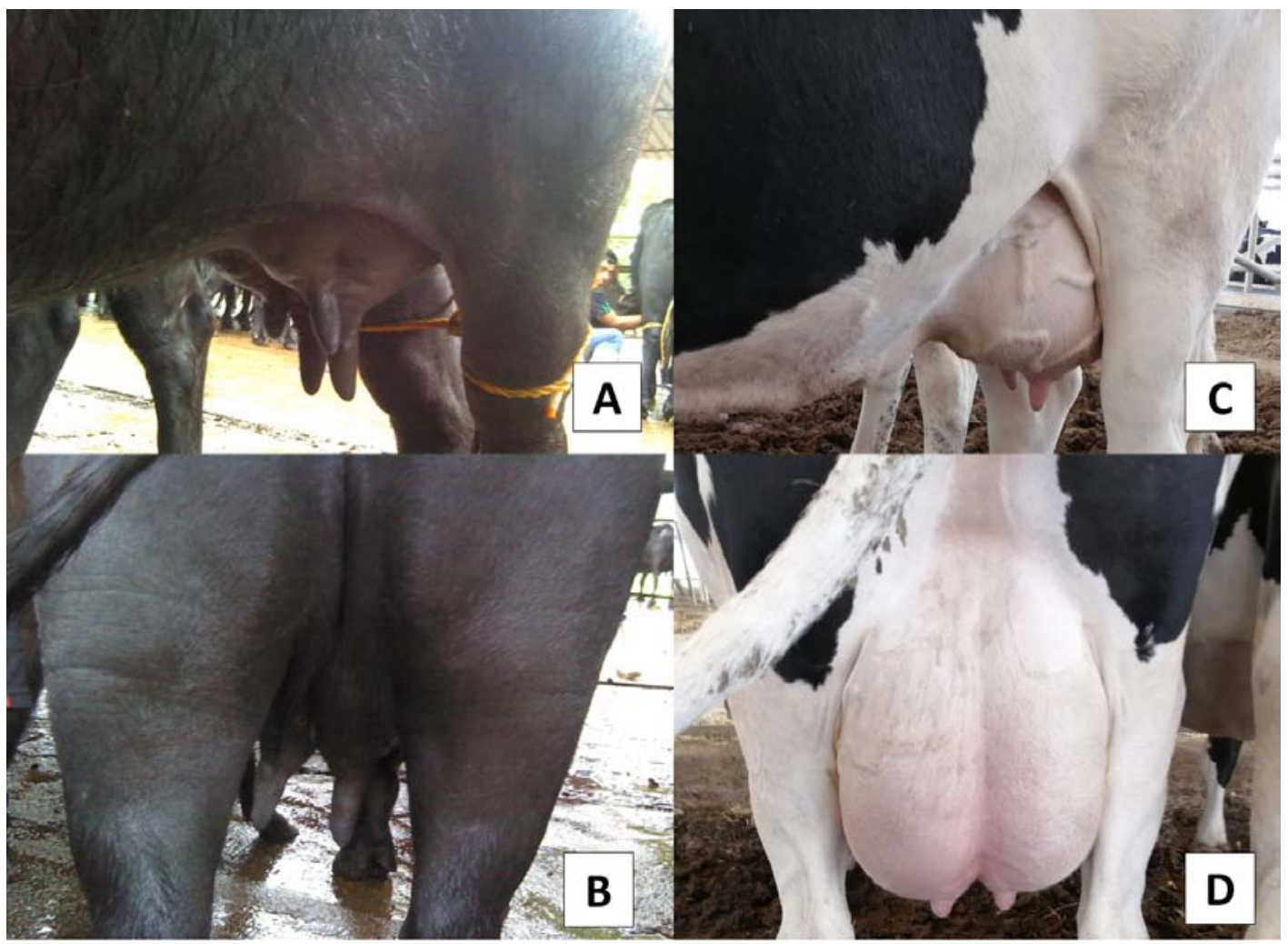

Figure 5: Udder of a dairy buffalo vs. a dairy cow. A. Lateral view of the udder of a dairy buffalo. B. Caudal view of the udder of a dairy buffalo. C. Lateral view of the udder of the Holstein dairy cow. D. Caudal view of the udder of the Holstein dairy cow. (Both are of parity number 3 ).

analyzed buffalo cows of different breeds, finding that most of those animals (56.46\%) had conical-shaped teats with an average length of $6.90 \mathrm{~cm}$. Riera-Nieves et al. [75] examined Holstein dairy cows, and their results show predominantly cylindrical-shaped teats $(48.30 \%)$ that averaged $5.90 \mathrm{~cm}$ in length. Buffalo cows thus have longer, thicker teats with a narrower canal and a tighter sphincter than dairy cows, suggesting a lower predisposition to mastitis but also a possible more difficult milk ejection $[72,74]$. Due to the different anatomy and physiology of the buffalo mammary gland, as compared to dairy cattle, numerous authors suggest adapting the milking routine (e.g., vacuum level, pulsation rate, and ratio) to the specific characteristics of these animals (e.g., Caria et al. [76]. Genetic selection means dairy cows now have certain physiological and anatomical characteristics that allow them to produce larger amounts of milk than buffalo cows. Their suspensory ligament and more-developed cistern will enable them to synthetize, transport, and store such quantities of milk, while the shape and size of their teats facilitate the use of milking machines. However, dairy buffalo cows show greater resistance to microorganisms that could predispose them to mastitis. Although the quantity of milk produced is less than in dairy cows, it has a higher dry matter content $[76,77]$.

\section{Allosucking}

Allosucking is understood as an infant's action that ingests milk from a female distinct from its genetic mother [78]. This behavior has often been reported in several ungulates, including pigs [79], reindeer [80], cattle, and buffaloes [81] sheep and red deer, among others [82]. See Figure 6 [7, 81]. Many hypotheses have been tested concerning the causes and consequences of this behavior. Roulin [83], for example, postulated that the female that allows the sucking of foreign calves' benefits because she can increase or maintain her prolactin concentration once her own offspring cease to stimulate her teats sufficiently while sucking. This may improve her immunity and resistance to pathogenic microorganisms. Víchová and Bartoš [82] found that allosucking in domestic cattle calves could be a compensatory behavior in case of low-weight births or a means of counteracting nutritional deficiencies. Their studies also showed a higher frequency of allosucking in female offspring and beef calves compared to males and calves of cross-bred species. Another observation is that sucking decreases in older calves, though a study by Paranhos da Costa et al. [84] did not report allosuckling behavior in the calves of two zebu breeds 


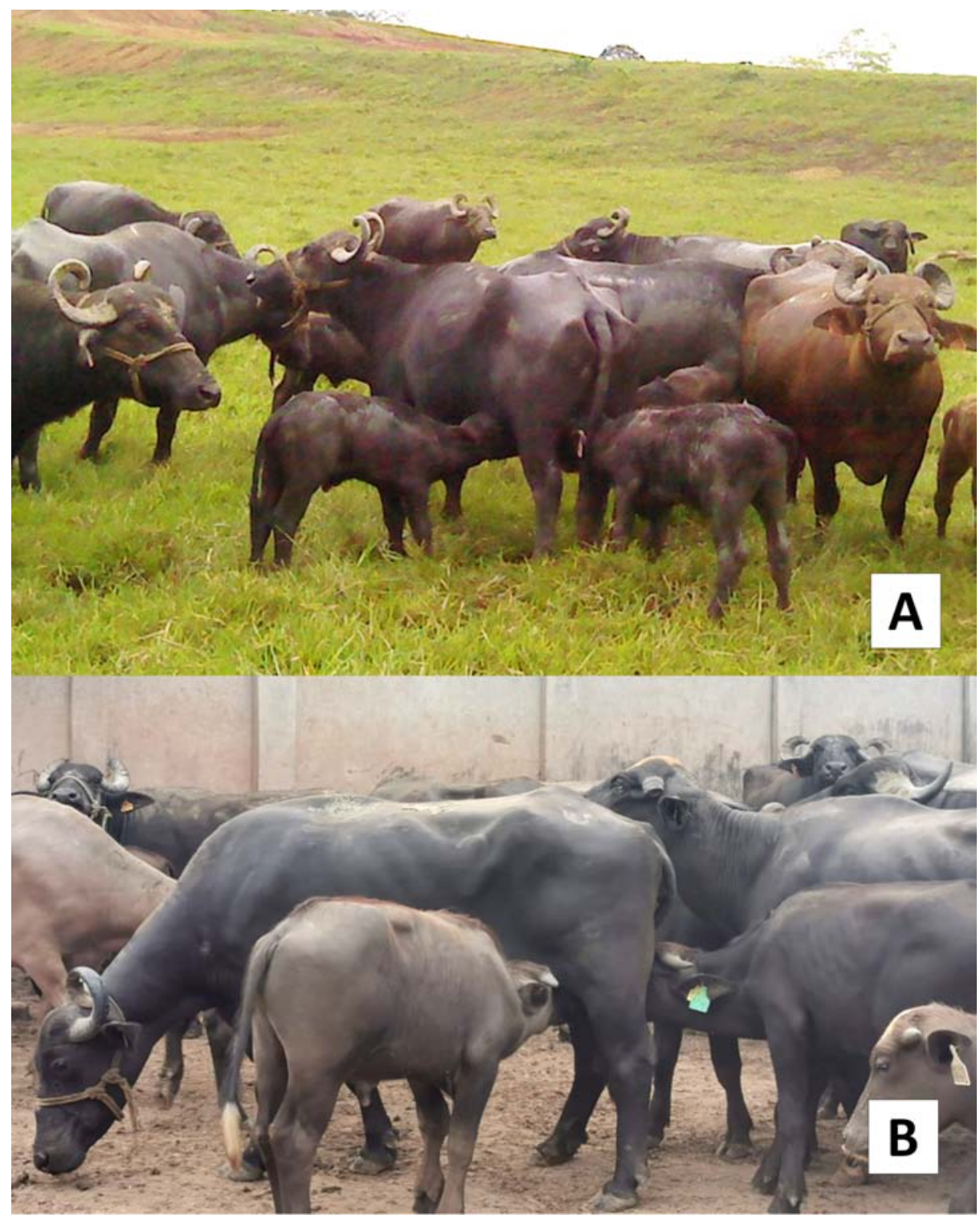

Figure 6: Communal nursing (allosucking). A frequent behavior seen in buffalo cows is the passive acceptance of nursing calves by other dams. This behavior is associated with various causes: the loss of the mother, low milk production that does not satisfy nutritional requirements, and rejection by the mother, which tends to occur only in primiparous females. Though this behavior is deemed altruistic [7], buffalo cows give priority to their offspring before ceding to the communal nursing behavior. Besides, not all female cows have the temperament required to accept calves from other dams [81]. A. Allosucking in an extensive system (Pasture). B. Allosucking in an intensive system (Confinement).

(Bos indicus, Nelore, and Gir) and one creole breed (Bos taurus, Caracu), kept on pasture from birth to weaning.

It seems that both buffalo and cattle may express allosucking as a consequence of insufficient calf nutrition $[85,86]$. For many years, it was believed that allosucking was a costly behavior that, moreover, entailed the risk that the cow could manifest aggression towards the foreign calf that tried to ingest her milk [83], and/or the transmission of pathogenic microorganisms through milk -as in the case of Johne's disease- since allosucking and communal nursing are considered risk factors for paratuberculosis in buffaloes [87]. But allosucking can also have positive consequences, such as reinforcing the calf's immune system through the ingestion of antibodies from a non-biological mother. It is important to emphasize that the monitoring of buffaloes over ten months by Andriolo et al. [88] showed that when maternal lactation of foreign offspring is allowed, the mother does not neglect her own offspring. Those authors further determined that allowing allosucking depends more on individual tolerance than group behavior by dams during lactation. Thus, allosucking has an individual component that reinforces calves' attempts to nurse. 


\section{IMMUNE SYSTEM AND DISEASE RESISTANCE}

The selection of disease-resistant species or breeds in production units is an ongoing enterprise around the world whose objective is to improve the health, welfare, and productivity of animals [89]. Cattle-breeders are attentive to this because of the economic losses caused by diseases, their treatment, and the culling of animals that fail to satisfy productive and/or reproductive parameters due to sub-clinical conditions [90]. Therefore, it is important to determine the degree of resistance or susceptibility to the most frequent diseases that impact the livestock industry.

Disease prevalence in cattle tends to result in significant economic losses. Animals in tropical areas are especially subject to high incidences of hoof diseases, mastitis, and ectoparasitic infections. River buffaloes, in contrast, manifest high resistance to these types of diseases because their habits and morphophysiology give them low susceptibility. The species-specific thermoregulation habit of wallowing, to give one example, can interrupt the life-cycle of ectoparasites. One consequence of this resistance is that mortality rates in adult buffalo are negligible [24]. Torres [25] sustains that buffaloes suffer lower incidences of mastitis because their anatomical and physiological characteristics generate barriers to the penetration of microorganisms into the cistern of the mammary gland, prevent occlusions of the orifice of the teat, and generate higher keratin levels (which has bactericide and bacteriostatic action) in the teat canal. Moreover, in natural environments with high humidity, this species shows low susceptibility to bacterial and fungal infections of the hooves [22].

\section{Mastitis}

In today's world, the health of the udders of milkproducing animals is important not only for dairy producers but also for consumers who are now more concerned with being informed about the measures taken to ensure the welfare of dairy-producing animals [91]. In the production chain of dairy products in general, mastitis in dairy cattle and buffaloes is a clinical condition that causes significant economic losses. It is considered one of the most serious limitations for this industry worldwide [26, 92, 93]. Reports indicate that Staphylococcus aureus ( $S$. aureus) is one of the most important causal agents of this infection and is responsible for contagious intramammary infections in dairy herds [94]. These bacteria cause clinical and sub-clinical mastitis in dairy cattle and buffaloes and pose a potential health problem for humans as well [93]. El-Ashker et al. [93] detected the Staphylococci in $21.1 \%$ of the milk samples drawn from dairy and buffalo cows. The results of a study by El-Ashker et al. [95] that analyzed samples from Holstein-Friesian bovines and Murrah buffaloes, for example, detected more samples that carried Staphylococcus aureus in conventional bovines as compared with buffaloes.

It appears, then, that dairy buffalo cows have lower incidences of mastitis than dairy cows, a condition attributed to morphophysiological differences in the former, which function as barriers that impede and/or prevent the access of the microorganisms that cause mastitides, such as Staphylococcus aureus and Clostridium perfringens. The characteristics that provide this marked resistance to the colonization of microorganisms include,

- A higher concentration of melanin pigments;

- A teat canal with a keratin epithelium thicker (than the one in cows);

- $\quad$ The thicker muscle layer of the sphincter around the teat canal (which has more tone, blood vessels, and nerve fibers).

Finally, the teat canal lumen is lower than in dairy cows $[73,96]$.

\section{Ectoparasites}

A study by Ybañez et al. [97] detected diverse ectoparasites in dairy bovines (Holstein) and river buffaloes (Murrah). Haematopinus spp and Rhipicephalus spp (lice and ticks, respectively) were identified, both known to be potential vectors of Mycoplasma spp. All the bovines were found to have ticks, but lice were absent; in contrast, the buffaloes had lice, but only one was found to have ticks. This difference could be due to the river buffalo's wallowing behavior in mud and the survival mechanism of lice, that is, the ability to close respiratory orifices underwater. These findings concur with the research by Benitez [98], who conducted an assay with infection by the tick Rhipicephalus, which is considered the ectoparasite with the most significant negative impact worldwide on dairy cattle. This study used a Mediterranean buffalo calf and a Holstein calf of the same age under identical environmental conditions. Findings showed that the number of mature ticks on these animals corresponded, respectively, to $5.4 \%$ and 
$12 \%$ of the initial larvae detected, indicating resistance levels of $94.5 \%$ in buffaloes and $88 \%$ in cattle, respectively. Observations also found a marked inflammatory reaction in the adherence area of the ticks in the buffalo, a process not seen in the bovine because the buffalo's immune system was more reactive to the allergenic components in the saliva of the Rhipicephalus [98]. Another possible explanation could be that the buffalo's thicker skin limits the tick's capacity to anchor its hypostome.

\section{Reproductive Pathologies}

Motta-Giraldo et al. [99] carried out a study that identified reproductive pathologies in buffalo cows and Holstein-Friesian cows in Colombia. Two management systems were examined: simple (one species per farm) and mixed (buffaloes and cattle kept together). The prevalence of reproductive pathologies in the mixed herds was $15.5 \%$ in buffalo cows and $55.8 \%$ in dairy cows, while the figures for the simple herds were $24.4 \%$ and $46.7 \%$, respectively. In both cases, significant between-species differences were found. This study also analyzed zootechnical indicators, where the buffalo cows showed a higher reproductive performance than the cows, expressed in a higher natality rate ( $84 \%$ for buffaloes vs. $72 \%$ for bovines), shorter calving intervals and open days, and a lower age at the time of the first birth, as the buffalo cows were more precocious (34.8 months) than the dairy cows (38.59). This occurred regardless of the type of herd but was more marked in the mixed herds than the simple ones [99].

\section{Lameness}

Cattle lameness is one of the most significant welfare and productivity issues in dairy farming, after mastitis. Lameness is an affection that generates significant economic losses in bovine production units. In the United States, these losses are estimated at around US $\$ 21$ per dairy cow with clinical lameness [100]. The main direct consequences are decreased productivity, high treatment costs, and deterioration of the body condition, but indirect impacts include the cost of eliminating animals and the loss of milk and derived products due to the therapeutic medications [101]. Reports on buffaloes, in contrast, suggest that this animal is more resistant to these problems, as indicated by De Rosa et al. [50] in a study conducted on 42 buffalo farms. They found that lameness with symptoms of limping was virtually non-existent in those animals. Limping is an important problem for the welfare of dairy cattle, usually associated with longterm pain and discomfort. The low incidence of limping in buffaloes could, once again, be due to certain morphological characteristics, since these animals have large hooves, elastic hocks, and thicker limbs that allow them to move in swampy, uneven terrain, and submerge for long periods in water [22]. Another explanation may be the fact that the dietary regimen of buffaloes is low in concentrates [5], compared to that of dairy cows since observations show that diets low in fiber content $(<18 \%)$ and with a high percentage of carbohydrates and proteins can be responsible for lameness in dairy cows [102]. It is important to note that another factor that may provide resistance to lameness in buffaloes involves the differences in their metabolism compared to cattle [5].

\section{LEVEL OF MILK PRODUCTION ACCORDING TO THE PRODUCTION SYSTEM}

Buffaloes are raised for two purposes simultaneously: producing milk and meat, though a third function may complement this since they can also work as draft animals. Worldwide, they are recognized, especially for their milk production and typical dairy products such as yogurt and mozzarella cheese. It is important to emphasize that buffaloes currently provide $13 \%$ of global milk production [6-8]. However, their contribution to the Americas remains low due to its recent introduction and a slow response by producers [103]. Much remains to be learned about the river buffalo. Virtually all aspects of production and its potential for generating products that can be inserted into markets for milk, meat, and their derivatives [103], especially where this species has been introduced recently into settings where it was not traditionally reared. For this reason, it is important to document the advantages and challenges that this species presents since these data could play a key role in promoting the political will required to support buffalo farming, and in convincing farmers to evaluate this species for their agricultural activities [9]. The academic sector must also assume responsibility for disseminating this information by analyzing options for developing the river buffalo as a potential alternative source of income and supporting the development of tropical regions where this species currently receives little attention [104].

Different production systems exist for buffalo cows and dairy cows, but the most common types are called intensive, semi-intensive, and extensive. Intensive systems predominate in temperate climate zones, while 


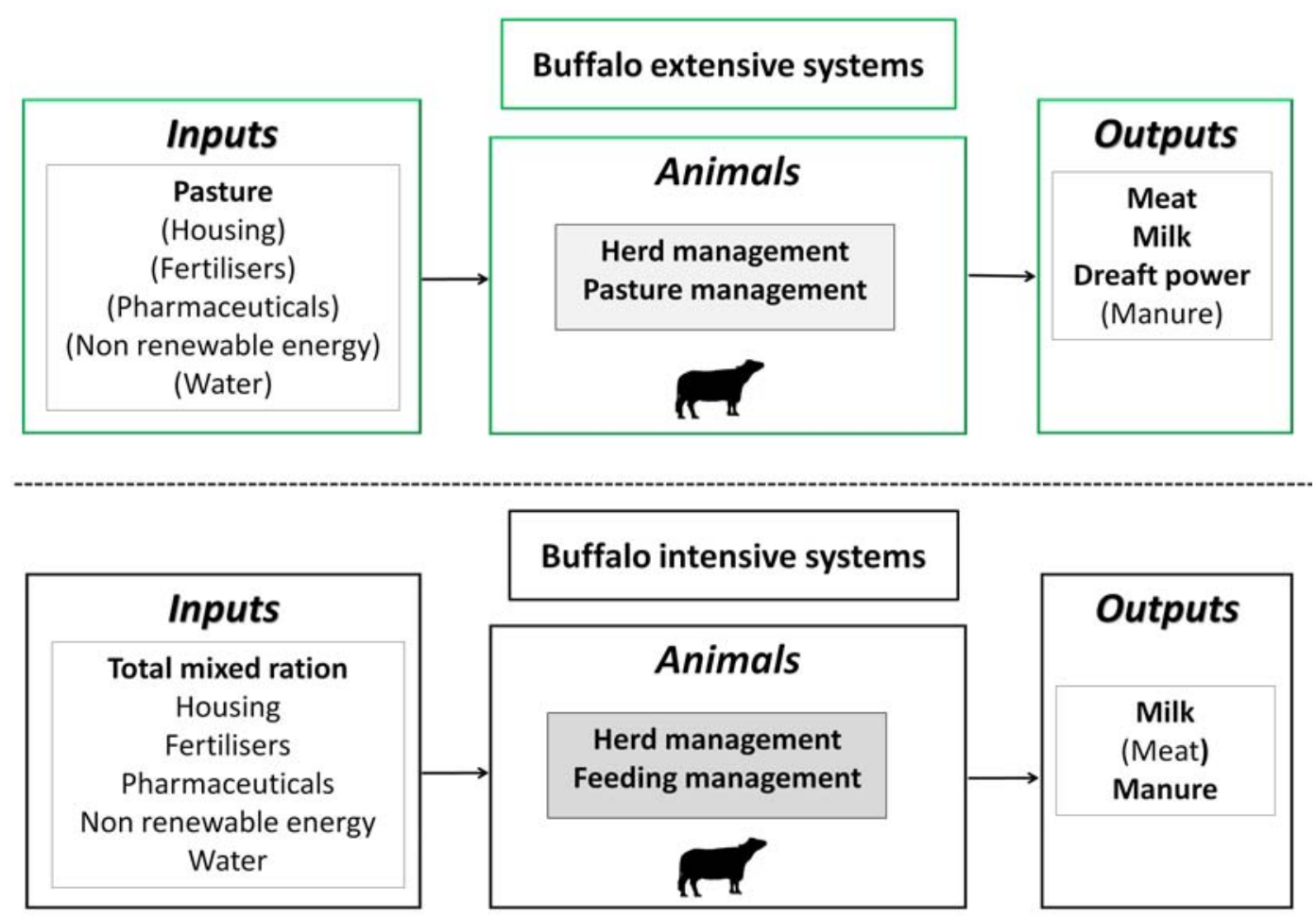

Figure 7: Extensive vs. intensive systems. A. Extensive production systems (EPS) refer to the use of broad extensions of land with a small workforce and low technological levels. They exist mainly in tropical zones and are associated mainly with natural forage and low dependence on external inputs. Initially, the buffalo was associated only with this type of production. B. Intensive production systems (IPS) are associated with small extensions of land, require a large workforce, and high technical specialization. IPS, therefore, are associated with high production volumes and a high dependence on external inputs that increase production efficiency and costs. IPS has specialized primarily in raising dairy cows; the application of intensive systems to river buffalo farming represents a relatively recent development. In bold high levels of inputs/outputs, in brackets low levels of inputs/outputs.

semi-intensive and extensive production units are more frequent in tropical zones, mainly in the form of doublepurpose systems. The main features that differentiate among these systems include the manner of exploiting the area, technological levels, zootechnical orientation, the species of cattle raised, and commercialization of products [105-107]. Because of their rustic nature, river buffaloes are associated with tropical regions characterized by swampy areas, high temperatures, high humidity, and low-to-medium quality forage [103]), but buffalo production systems have evolved, and today there is a wide variety of farming systems that reflects differences in the regions of the world where buffalo-raising has been introduced [50].

\section{Intensive Systems}

Cattle breeds specialized in milk production are more common in temperate zones where intensive production systems predominate. In these systems, animals remain housed most of the time, and nutritional supplementation allows them to achieve high production [50, 108]. Cosmopolitan cattle breeds are, however, also being raised in tropical zones. Besides, the cross-breeding of Bos taurus and Bos indicus has been conducted to achieve greater resistance to tropical climate conditions and tick infections while simultaneously favoring milk production [15]. See Figure 7 [26].

\section{Extensive Systems}

The river buffalo, which has been raised principally in tropical climates with a double purpose (i.e., milk and meat production), has been adapted to temperate climates with intensification levels similar to those typically used with species specialized in milk production. These systems rely on forage as the primary feeding source with minimal supplementation $[109,110]$ and reduced environmental impact [111] (Figures 8, 9).

As shown in Figure 5, the udders of buffalo and dairy cows present anatomical differences; however, the sensory stimuli provided by the calf and the 


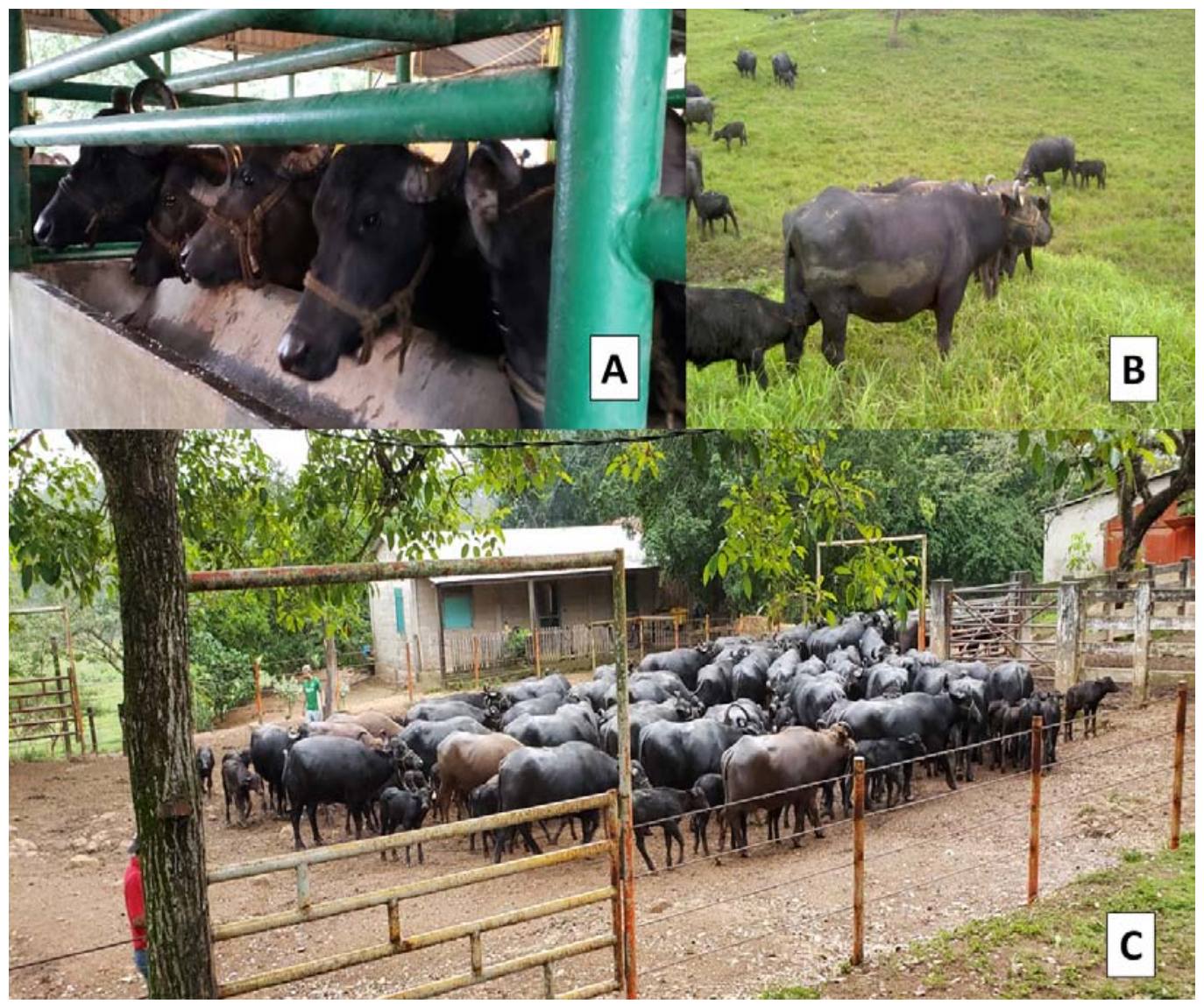

Figure 8: Types of buffalo production systems. A. Intensive milk production system with separation of calves only a few days after birth (Confinement). B. Meat production system based on pasture (extensive); all the milk produced is destined for the calves. C. Double-purpose is a semi-intensive production system with milk and meat production; here, calves have access to nursing only after milking.

application of exogenic oxytocin can produce similar physiological responses in both species [73,74].

\section{PERSPECTIVES}

The ever increasing demand for food requires research into alternative products for human consumption but also calls for implementing production systems that are more efficient and sustainable than traditional schemes. It is in this context that the studies mentioned above show that introducing the river buffalo is a viable option since this animal can fulfill the functions of producing meat and milk, particularly in tropical areas with availability of water for wallowing. This requires, however, becoming familiar with these animals' characteristics and obtaining a thorough understanding of their particularities, advantages, and challenges. Once this knowledge has been acquired, it will be possible to effectively assess whether the buffalo can potentially replace other farm species. Likewise, it is important to understand the biological aspects associated with the health of these animals in terms of susceptibility to certain harmful agents, such as ticks in tropical areas. Finally, the decision to replace cattle or zebus with buffaloes in individual production units depends on specific economic aspects affecting farm profitability.

\section{APPLICATIONS AND CONCLUSIONS}

This review has shown that although river buffaloes and domestic bovines belong to the same Bovidae family and seem quite similar, awareness of the anatomical, physiological, and behavioral differences among Bos taurus, Bos indicus, and the buffalo will make it possible to:

1. Select the animal species that best adapt to the environmental conditions of the diverse livestock production systems.

2. Adapt the installations of production units and develop appropriate technologies for milking equipment specifically-adapted to the buffalo's anatomical characteristics instead of using the same equipment as with dairy cows. 


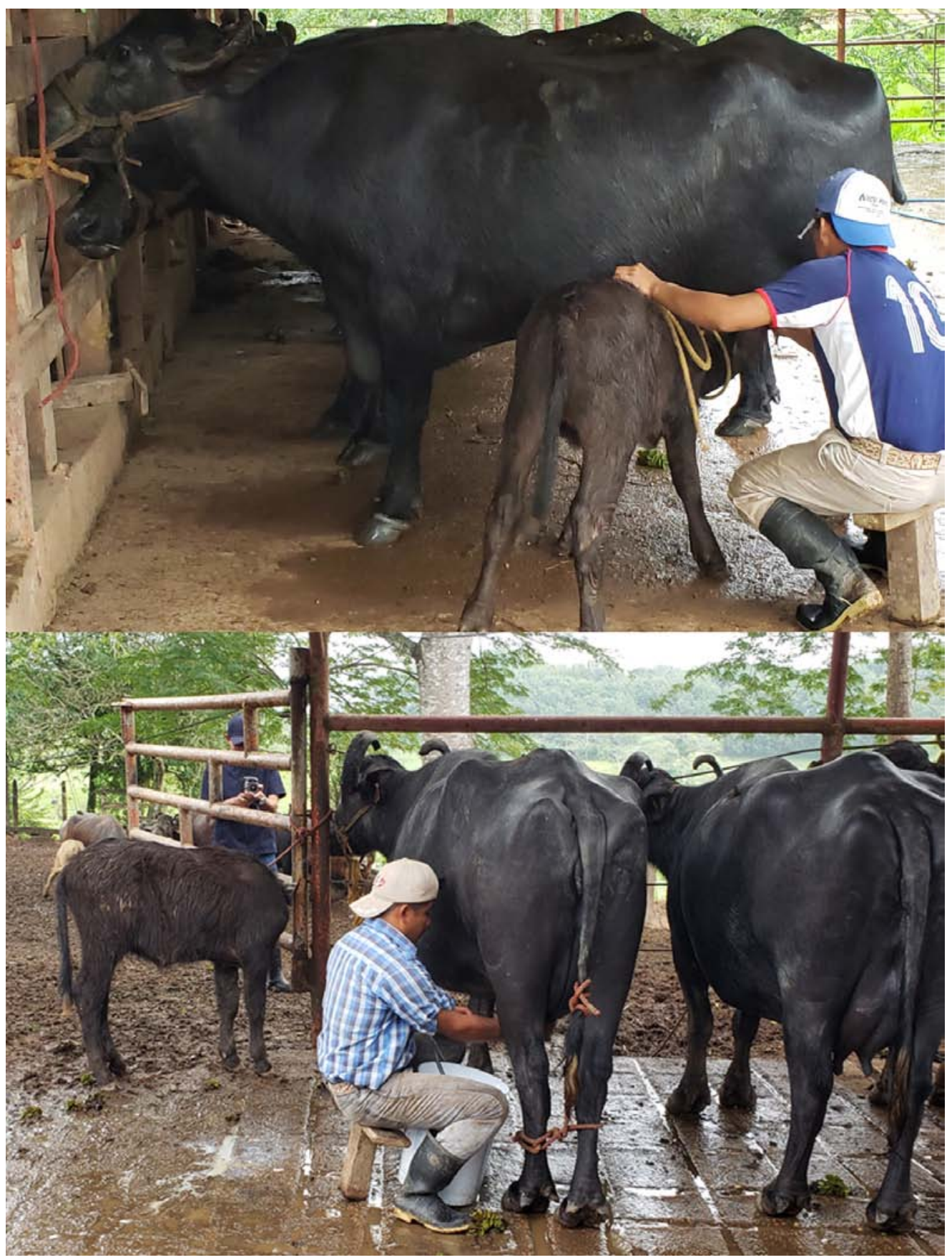

Figure 9: Importance of the calf in milk ejection. Milk ejection can be induced by various stimuli that facilitate the emptying of the mammary gland. Using calves as a tactile sensory stimulus is very frequent. This stimulus is transmitted through the spinal cord to the hypothalamus and neurohypophysis, where oxytocin is synthesized and released to contract the myoepithelial cells that surround the alveolus, thus inducing milk ejection.

3. Avoid making the same errors that marked the development of highly-specialized dairy production, which brought such consequences as a higher predisposition to infectious and metabolic diseases than rustic animals like the river buffalo.

4. Implement production strategies that do not compromise animal welfare.

\section{REFERENCES}

[1] Guerrero-Legarreta I, Napolitano F, Cruz-Monterrosa R, Mora-Medina $\mathrm{P}$, Braghieri $\mathrm{A}$, et al. River buffalo meat production and quality. Appl Anim Sci 2020; 36: (In review). https://www.journals.elsevier.com/applied-animal-science

[2] Mota-Rojas D, Orihuela A, Strappini-Asteggiano A, CajiaoPachón MN, Agüera-Buendía $\mathrm{E}$, Mora-Medina $\mathrm{P}$, et al. Teaching animal welfare in veterinary schools in Latin America. Int J Vet Sci Med 2018; 6: 131-40. https://doi.org/10.1016/j.ijvsm.2018.07.003 
[3] Orihuela A, Mota-Rojas D, Velarde A, Strappini-Asteggiano $A$, Thielo de la Vega L, Borderas-Tordesillas $F$, et al. Invited review: environmental enrichment to improve behaviour in farm animals. CAB Reviews 2018; 13(059): 1-25.

https://doi.org/10.1079/PAVSNNR201813059

[4] Mota-Rojas D, Broom DM, Orihuela A, Velarde A, Napolitano $\mathrm{N}$, Alonso-Spilsbury M. Effects of human-animal relationship on animal productivity and welfare. J Anim Behav Biometeorol 2020; 8: 196-205.

https://doi.org/10.31893/jabb.20026

[5] Napolitano F, Pacelli C, Grasso F, Braghieri A, De Rosa G. The behaviour and welfare of buffaloes (Bubalus bubalis) in modern dairy enterprises. Animal 2013; 7: 1704-13. https://doi.org/10.1017/S1751731113001109

[6] Napolitano F, Mota-Rojas D, Berdugo GJA, González LM, Mora-Medina P, Ruíz BJD, et al. Dairy buffalo welfare at labour. Electronic Journal Ganaderia.com 2018.

[7] Napolitano F, Serrapica F, Braghieri A, Masucci F, Sabia E, De Rosa G. Human-Animal Interactions in Dairy Buffalo Farms. Animals 2019; 9: 246. https://doi.org/10.3390/ani9050246

[8] Napolitano F, Mota-Rojas D, Mora-Medina P, BerdugoGutiérrez J, Ruíz-Buitrago JD, Nava J, et al. Dairy Buffalo welfare and productivity. Entorno Ganadero 2019; 15: 38-48.

[9] Napolitano F, Arney D, Mota-Rojas D, De Rosa G. Chapter 17. Reproductive technologies and animal welfare. In: Presicce G, editor. Reproductive technologies in animals. 1st. Ed. Italy: S\&T Sciences/Elsevier Press; Amsterdam, The Netherlands 2020; p. 266. https://doi.org/10.1016/B978-0-12-817107-3.00017-5

[10] González-Lozano M, Mota-Rojas D, Orihuela A, MartínezBurnes J, Di Francia A, Braghieri A, et al. Behavioral, physiological, and reproductive performance of buffalo cows during eutocic and dystocic parturitions. Appl Anim Sci 2020; 36: 407-22.

https://doi.org/10.15232/aas.2019-01946

[11] Mota-Rojas D, Martínez-Burnes J, Napolitano F, DomínguezMuñoz M, Guerrero-Legarreta I, Mora-Medina P, et al. Invited review: Dystocia: Factors affecting parturition in domestic animals. CAB Reviews 2020; 15(013): 1-14.

https://doi.org/10.1079/PAVSNNR202015013

[12] Gutiérrez VA, Hurtado LN, Cerón-Muñoz M. Estimates of correction factors for lactation length, age and calving season in buffaloes of Colombian Atlantic Coast. Livest Res Rural Dev 2006; 18: http://www.Irrd.org//rrd18/4/guti18050. htm

[13] Mendes AJ, Lima F. Aspectos nutricionales del búfalo. Tecnología en Marcha, SeDAFP y Universidad Popular de la Chontalpa 2011; 516: 105-20.

[14] García AR, Matos LB, Júnior L, de Brito J, Nahúm BDS, Araújo CVD, Santos AX. Physiological features of dairy buffaloes raised under shade in silvipastural systems. Pesq Agropec Bras 2011; 46: 1409-14. https://doi.org/10.1590/S0100-204X2011001000039

[15] Romero SD, Pérez de León AA. Bubalinocultura en México: retos de industria pecuaria naciente. Logros y Desafíos de la Ganadería Doble Propósito 2014; 6: 15.

[16] Crudeli GA, Konrad JL, Patiño EM. Reproducción en búfalas. 1st ed. Buenos Aires, Argentina: Moglia 2016.

[17] USDA-United States Department of Agriculture. Milk Production In: Economics, Statistics and Market Information System (ESMIS) 2018: Avaliable from: https://usda.library. cornell.edu/concern/publications/h989r321c?locale=en

[18] AIA- Associazione Italiana Allevatori. Controles Oficiales de productividad de la leche en Italia 2018: Avaliable from: http://bollettino.aia.it/Contenuti.aspx?CD_GruppoStampe=TB \&CD_Specie=C4

[19] Mattapallil MJ, Ali S. Analysis of conserved microsatellite sequences suggests closer relationship between water buffalo Bubalus bubalis and sheep Ovis aries. DNA Cell Biol 1999; 18: 513-19.

https://doi.org/10.1089/104454999315231

[20] Quintanilla-Quintero SR. Variación genética de una población colombiana de búfalo de agua (Bubalus bubalis) a través de un panel de microsatélites relacionados con la especie. Doctoral dissertation. Uppsala: Universidad Nacional de Colombia 2014.

[21] Bertoni MA, Álvarez MAG, Mota-Rojas D. Desempeño productivo de los búfalos y sus opciones de desarrollo en las regiones tropicales. Soc Rural Prod Med Amb 2019; 38: 5980.

[22] Barboza JG. Bondades ecológicas del búfalo de agua: camino hacia la certificación. Rev Tec Marcha 2011; 24: 82.

[23] Mota-Rojas D, Napolitano F, Bertoni MA, Gómez-Prado J, Mora-Medina P, Cruz-Monterrosa R, et al. Thermal biology in river buffalo in the humid tropics: neurophysiological and behavioral responses. Int J Vet Sci Med 2020; 8: (In review). https://www.tandfonline.com/toc/tvsm/current

[24] Almaguer PY. El búfalo, una opción de la ganadería. Revista Electrónica de Veterinaria 2007; 8: 1-23. https://www.redalyc.org/articulo.oa?id=63612734014

[25] Torres EG. Búfalos: una especie promisora. Sitio Argentino de Producción Animal 2009. www.produccion-animal.com.ar

[26] Mota-Rojas D, De la Rosa G, Mora-Medina P, Braghieri A, Guerrero LI, Napolitano F. Dairy buffalo behaviour and welfare from calving to milking. CAB Reviews 2019(035); 14: $1-14$. https://doi.org/10.1079/PAVSNNR201914035

[27] Puppo S, Grandoni F. Microflora ruminale in bufali e bovini alimentati con diete fibrose. In: Atti Convegno Miglioramento dell'efficienza produttiva e riproduttiva della specie bubalina. Potenza, Italy 1993; 307-21.

[28] Jalaludin S, Ho YW, Abdullah N, Kudo $H$. Rumen microorganisms of the water buffalo. Buffalo J 1992; 8: 21120.

[29] Singh S, Pradhan K, Bathia SK. Relative ruminal microbial profile of cattle and buffalo fed wheat straw-concentrate diet. Indian J Anim Sci 1992; 62: 1197-1202.

[30] Ranjhan S. Nutrition of river buffaloes in Southern Asia. In: Tulloh J, Holmes $\mathrm{H}$, editors. Buffalo production. $1^{\text {st }}$ ed. Asia 1992; pp. 111-34.

[31] Fundora O, Quintana FO, González ME. Performance and carcass composition in river buffaloes fed a mixture of star grass, natural pastures and native legumes. Cuban J Agric Sci 2004; 38: 41.

[32] El-Salam M, El-Shibiny. A comprehensive review on the composition and properties of buffalo milk. Dairy Sci Tech 2011; 91: 663-99. https://doi.org/10.1007/s13594-011-0029-2

[33] Riaño J, Narváez S. Composición, beneficios y enfermedades asociadas al consumo de leche de vaca. Revista Sthetic \& Academy 2015; 13-24.

[34] Neath KE, Del Barrio AN, Lapitan RM, Herrera JRV, Cruz LC, Fujihara T. Muroya S, Chikuni K, Hirabayashi M, Kanai $\mathrm{Y}$. Protease activity higher in postmortem water buffalo meat than Brahman beef. Meat Sci 2007; 77: 389-96. https://doi.org/10.1016/j.meatsci.2007.04.010

[35] Kandeepan G, Biswas S, Rajkumar RS. Buffalo as a potential food animal. Int J Livest Prod 2009; 1: 001-005.

[36] Angulo RA, Noguera RR, Berdugo JA. The water buffalo (Bubalus bubalis) an efficient user of nutrients; aspects on fermentation and ruminal digestion. Livest Res Rural Dev 2005; 17: http://www.Irrd.org//rrd17/6/angu17067.htm

[37] Paul SS, Lal D. Nutrient requirements of buffaloes AzadpurDellhi: Satish Serial Publishing House 2010; 137.

[38] Leao MI, Valadares RF, Coelho da Silva J F, Valadares Filho SDC, Torres RDA. Biometría do trato digestivo de bubalinos 
e bovinos. Rev Bras Zootec 1985; 14: 559-64.

[39] Bartocci S, Amici A, Verna M, Terramoccia S, Martillotti F. Solid and fluid passage rate in buffalo, cattle and sheep fed diets with different forage to concentrate ratios. Livest Prod Sci 1997; 52: 201-08.

https://doi.org/10.1016/S0301-6226(97)00132-2

[40] Sideney J, Lyford J. Crecimiento y desarrollo del aparato digestivo de los Rumiantes. In: Chuch, D, editor. El rumiante, fisiología digestiva y nutrición. 1st ed. Zaragoza, España: Editorial Acribia S.A. 1993; pp. 47-68.

[41] Pant HC, Roy A. Studies on the rumen microbial activity of buffalo and zebu cattle. Concentrations of micro-organisms and total and particulate nitrogen in the rumen liquor. Indian J Anim Sci 1970; 40: 600-9.

[42] Homma H. Cellulase activities of bacteria in liquid and solid phases of the rumen digesta of buffaloes and cattle. Nihon Chikusan Gakkaihō. Anim Sci Technol (Jpn.) 1986; 57: 33641. https://doi.org/10.2508/chikusan.57.336

[43] Franzolin R, Dehority BA. Comparison of protozoal populations and digestion rates between water buffalo and cattle fed an all forage diet. J Appl Anim Res 1999; 16: 3346.

https://doi.org/10.1080/09712119.1999.9706260

[44] Fundora O. Comportamiento de búfalos de agua (Bubalus bubalis) de la raza Buffalypso en sistemas de alimentación basados en pastoreo: quince años de investigaciones en el Instituto de Ciencia Animal. Rev Cubana Cienc Agr 2015; 49: 161-71.

[45] Sane CR, Kaikini AS, Deshpande BR, Koranne GS, Desai VG. Study of biometry of genitalia of Jaffri buffalo-cows (Bos bubalis). Indian Vet J 1965; 42: 591

[46] Konrad JL. Inseminación artificial. In: Crudeli G, editor. Reproducción en Búfalas. 1st ed. Argentina: Ediciones Moglia 2016; 24: pp. 175-82.

[47] De Rosa G, Grasso F, Winckler C, Bilancione A, Pacelli C, Masucci $F$, et al. Application of the Welfare Quality protocol to dairy buffalo farms: prevalence and reliability of selected measures. J Dairy Sci 2015; 98: 6886-96. https://doi.org/10.3168/jds.2015-9350

[48] Carvalho N, Gimenes L, Reis EL, Cavalcante AK, Mello JE, Nichi $M$, et al. Biometry of genital system from buffalo (Murrah) and bovine (Nelore) females. Revista Veterinaria IN Proceedings 2010; 21: 276-9.

[49] Zicarelli L. Estacionalidad Reproductiva en Búfalas. In: Crudeli G, editor. Reproducción en Búfalas. 1st ed. Argentina: Ediciones Moglia 2016; pp. 73-94.

[50] De Rosa G, Grasso F, Pacelli C, Napolitano F, Winckler C. The welfare of dairy buffalo. Ital J Anim Sci 2009; 8: 16. https://doi.org/10.4081/ijas.2009.s1.103

[51] Muñoz-González JC, Huerta-Bravo M, Lara Bueno A, Rangel Santos R, Arana R. Production and nutritional quality of forages in conditions Humid Tropics of Mexico. Rev Mex Cien Agric 2016; 7: 3315-3327.

https://doi.org/10.29312/remexca.v0i16.399

[52] Crudeli GA. Fisiología reproductiva del búfalo. Tecno Marcha 2011; 24: 74-81.

[53] Sánchez JA, Romero $\mathrm{MH}$, Suárez V. Reproductive seasonality of female buffalo (Bubalus bubalis). Rev Investig Vet Perú 2017; 28: 606-18. https://doi.org/10.15381/rivep.v28i3.13289

[54] Gómez DAA, Muñoz MFC, Lugo AH. El búfalo como animal productor de carne: producción y mejoramiento genético. Rev Lasallista Invest 2007; 4: 43-9.

[55] Martínez A, Ray JV, García López R, Benítez D, Guevara O. Comportamiento de algunos indicadores productivos y reproductivos del búfalo de río en la provincia Granma. Rev Cubana Cien Agric 2009; 43: 127-130.
Bavera GA. Búfalo de agua: razas. Cursos de Producción Bovina de Carne, FAV UNRC. Sitio Argentino de Producción Animal 2005.

[57] Jainudeen MR, Hafez ESE. Reproductive cycles, Cattle and buffalo. In: Hafez SE, Hafez B, editors. Reproduction in farm animals. 7th ed. Philadelphia: Lippincott Williams \& Vilson 2000; pp. 157-171.

https://doi.org/10.1002/9781119265306.ch11

[58] Barile VL. Reproductive efficiency in female buffaloes. Buffalo Production and Research. FAO Technical Series 2005; 77-108.

[59] Saini MS, Dhanda OP, Singh N, Georgie GC. The effect of improved management on reproductive performance of pubertal buffalo heifers during summer. Indian J Dairy Sci 1998; 51: 250-3.

[60] Bedoya C, Mira T, Guarín J, Berdugo J. Parámetros reproductivos del búfalo de agua (Bubalus bubalis) en el sur de Córdoba. Costa Norte Colombiana. In: VI World Buffalo Congress, The Buffalo: An alternative for Animal Agricultural in the Third Millenium: Venezuela 2002; pp. 271-75.

[61] Anitha A, Rao KS, Suresh J, Moorthy PS, Reddy YK. A body condition score (BCS) system in Murrah buffaloes. Buffalo Bull 2011; 30: 79-96.

[62] Di Palo R, Ariota B, Zicarelli F, De Blasi M, Zicarelli G, Gasparrini B. Incidence of pregnancy failures in buffaloes with different rearing system. Ital J Anim Sci 2009; 8: 21. https://doi.org/10.4081/ijas.2009.s2.619

[63] Mozo J, Emre Y, Bouillaud F, Ricquier D, Criscuolo F. Thermoregulation: what role for UCPs in mammals and birds? Biosci Rep 2005; 25: 227-49. https://doi.org/10.1007/s10540-005-2887-4

[64] Blackshaw JK, Blackshaw AW. Heat stress in cattle and the effect of shade on production and behaviour: a review. Aust $J$ Exp Agric 1994; 34: 285-95.

https://doi.org/10.1071/EA9940285

[65] Abdelatif AM, Alameen AO. Influence of season and pregnancy on thermoregulation and haematological profile in crossbred dairy cows in tropical environment. Glob Vet 2012 9:334-40.

[66] Berdugo-Gutiérrez J, Mota-Rojas D, Napolitano F, Nava J, Ruíz-Buitrago JD, González-López C, Guerrero-Legarreta I. Heat stress in river buffalo. Rev Entorno Ganadero 2019; 15 26-36.

[67] Ablas DDS, Titto EAL, Pereira AMF, Titto CG, Leme TDC. Behaviour of grazing water buffaloes depending on the availability of shade and water for imersion. Ciênc Anim Bras 2007; 8: 167-76.

[68] Marai IFM, Haeeb AAM. Buffalo's biological functions as affected by heat stress - A review. Livest Sci 2009; 127: 8994. https://doi.org/10.1016/j.livsci.2009.08.001

[69] Soroko M, Howell K, Zwyrzykowska A, Dudek K, Zielińska P Kupczyński R. Maximum eye temperature in the assessment of training in racehorses: correlations with salivary cortisol concentration, rectal temperature and heart rate. J Eq Vet Sci 2016; 45: 39-45.

https://doi.org/10.1016/j.jevs.2016.06.005

[70] Casas-Alvarado A, Mota-Rojas D, Hernández-Ávalos I, Mora-Medina $\mathrm{P}$, Olmos-Hernández $\mathrm{A}$, Verduzco-Mendoza $\mathrm{A}$, Martínez-Burnes J. Advances in infrared thermography: surgical aspects, vascular changes and pain monitoring in veterinary medicine. J Therm Biol 2020; (In review).

[71] Davidson AP, Stabenfeldt GH. Aspectos anatómicos de la glándula mamaria. In: Bradley $\mathrm{G}$, editor. Fisiología Veterinaria. 5th ed. España: Elsevier Saunders 2014; pp. 408-459.

[72] Thomas CS, Svennersten-Sjaunja K, Bhosrekar MR, Bruckmaier RM. Mammary cisternal size, cisternal milk and 
milk ejection in Murrah buffaloes. J Dairy Res 2004; 71: 162-8.

https://doi.org/10.1017/S0022029904000081

[73] Espinosa Y, Ponce P, Capdevila J. Efecto de la estimulación con bucerro, oxitocina y manual sobre los indicadores de ordeño en búfalas. Rev Salud Anim 2011b; 33: 90-6.

[74] Espinosa Y, Ponce P, Capdevila J, Riera M, Nieves L. Morfobiometría de la ubre en búfalas lecheras en rebaños del occidente de Cuba. Rev Cient FCV-LUZ 2011a; 21: 5338.

[75] Riera-Nieves M, Rodríguez-Márquez JM, Perozo-Prieto E, Rizzi R, Pedron, O. Comparison of morphological traits of teats in three dairy breed. Rev Cient FCV-LUZ 2006; 16 : 315-24.

[76] Caria M, Murgia L, Pazzona A. Effects of the working vacuum level on mechanical milking of buffalo. J Dairy Sci 2011; 94: 1755-61.

\section{https://doi.org/10.3168/jds.2010-3134}

[77] Caria M, Boselli C, Murgia L, Rosati R, Pazzona A. Effect of vacuum level on milk flow traits in Mediterranean Italian buffalo cow. Ital J Anim Sci 2012; 11:e25. https://doi.org/10.4081/ijas.2012.e25

[78] Roulin A, Heeb $P$. The immunological function of allosuckling. Ecol Lett 1999; 2: 319-24. https://doi.org/10.1046/j.1461-0248.1999.00091.x

[79] Špinka M. How important is natural behaviour in animal farming systems? Appl Anim Behav Sci 2006; 100: 117-28. https://doi.org/10.1016/j.applanim.2006.04.006

[80] Engelhardt SC, Weladji RB, Holand $\varnothing$, Røed KH, Nieminen M. Allonursing in reindeer, Rangifer tarandus: a test of the kin-selection hypothesis. J Mammal 2016; 97: 689-700. https://doi.org/10.1093/jmammal/gyw027

[81] Mora-Medina P, Napolitano F, Mota-Rojas D, Berdugo J, Ruiz-Buitrago J, Guerrero-Legarreta I. Imprinting, Sucking and allosucking behaviors in buffalo calves. J Buffalo Sci 2018; 7: 43-48. https://doi.org/10.6000/1927-520X.2018.07.03.2

[82] Víchová J, Bartoš L. Allosuckling in cattle: gain or compensation? Appl Anim Behav Sci 2005; 94: 223-35. https://doi.org/10.1016/j.applanim.2005.02.015

[83] Roulin A. The Neuroendocrine Function of Allosuckling. J Ethol 2003; 109: 185-95. https://doi.org/10.1046/j.1439-0310.2003.00870.x

[84] Paranhos da Costa MJR, Albuquerque LG, Eler JP, de Vasconcelos Silva JAI. Suckling behaviour of Nelore, Gir and Caracu calves and their crosses. Appl Anim Behav Sci 2006; 101: 276-87.

https://doi.org/10.1016/j.applanim.2006.02.006

[85] Murphey RM, Paranhos da Costa MJR, Gomes da Silva R, de Souza R. Allonursing in river buffalo, Bubalis bubalis: nepotism, incompetence, or thievery? Anim Behav 1995; 49: 1611-6.

https://doi.org/10.1016/0003-3472(95)90083-7

[86] Paranhos da Costa MJR, Simplicio de Oliveira JF, Schmidek WR. Suckling and Allosuckling in river buffalo calves and its relation with weight gain. Appl Anim Behav Sci 2000; 66: 110.

\section{https://doi.org/10.1016/S0168-1591(99)00083-0}

[87] Dalto AC, Bandarra PM, Pavarini SP, Boabaid FM, de Bitencourt AP G, Gomes MP, Chies J, Driemeier D, da Cruz CEF. Clinical and pathological insights into Johne's disease in buffaloes. Trop Anim Health Prod 2012; 44: 1899-1904. https://doi.org/10.1007/s11250-012-0154-9

[88] Andriolo A, Paranhos da Costa MJR, Schmidek WR. Suckling behaviour in water buffalo (Bubalus bubalis): development and individual differences. Rev Etol 2001; 3: 129-36.
$[89]$

Stear MJ, Bishop SC, Mallard BA, Raadsma H. The sustainability, feasibility and desirability of breeding livestock for disease resistance. Res Vet Sci 2001; 71: 1-7. https://doi.org/10.1053/rvsc.2001.0496

[90] Frias M, Landi H, Montes D, Parodi FP. Análisis comparativo de la salud y costo en el período vaca parida en rodeos lecheros. InVet 2011; 13: 17-23.

[91] Hogeveen H, Huijps K, Lam TJGM. Economic aspects of mastitis: new developments. New Zealand Vet J 2011; 59: 16-23.

https://doi.org/10.1080/00480169.2011.547165

[92] Mota-Rojas D, Napolitano F, Martínez-Burnes J, De Rosa G, Braghieri A, Orihuela MA. Distocia en búfalas: Complicaciones obstétricas. Agro Meat 2019b; 5: 1-10.

[93] El-Ashker M, Gwida M, Monecke S, El-Gohary F, Ehricht R, Elsayed M, Paul A, El-Fateh M, Maurischat S. Antimicrobial resistance pattern and virulence profile of $S$. aureus isolated from household cattle and buffalo with mastitis in Egypt. Vet Microbiol 2020; 240: 108535.

https://doi.org/10.1016/j.vetmic.2019.108535

[94] Lozano C, Gharsa H, Ben Slama K, Zarazaga M, Torres C. Staphylococcus aureus in animals and food: Methicillin resistance, prevalence and population structure. A review in the African continent. Microorganisms 2016; 4: 12. https://doi.org/10.3390/microorganisms4010012

[95] El-Ashker M, Gwida M, Tomaso H, Monecke S, Ehricht R, ElGohary F, Hotzel H. Staphylococci in cattle and buffaloes with mastitis in Dakahlia Governorate, Egypt. J Dairy Sci 2015; 98: 7450-9. https://doi.org/10.3168/jds.2015-9432

[96] Sollecito N, Lopes L, Leite R. Somatic cell count, profile of antimicrobial sensitivity and microrganisms isolated from buffalo mastitis: A breaf review. Rev Bras Med Vet 2011; 33 : 18-22.

[97] Ybañez AP, Ybañez RHD, Armonia, RKM, Chico JKE, Ferraren KJV, Tapdasan EP, Salces CB, Maurillo BCA, Galon EMS, Macalanda AMC, Moumouni PFA, Xuan X. First molecular detection of Mycoplasma wenyonii and the ectoparasite biodiversity in dairy water buffalo and cattle in Bohol, Philippines. Parasitol Int 2019; 70: 77-81. https://doi.org/10.1016/j.parint.2019.02.004

[98] Benitez D, Cetrá B, Florin-Christensen M. Rhipicephalus (Boophilus) microplus ticks can complete their life cycle on the water buffalo (Bubalus bubalis). J Buffalo Sci 2012; 1: 193-7. https://doi.org/10.6000/1927-520X.2012.01.02.11

[99] Motta-Giraldo JL, Waltero-García I, Abeledo-García MA Miranda I, Campos-Pipaon R. Main reproductive disorders in buffaloes and cows in mixed herds and of one species in the department of Caquetá, Colombia. Rev Med Vet Zoot 2014; 61: 228-40.

https://doi.org/10.15446/rfmvz.v61n3.46870

[100] Wells SJ, Trent AM. Clinical lameness in dairy cows in the Midwestern United States. A Preliminary Report. Bov Pract Proceed 1999; 23: 148-9.

[101] García-Bracho D, Hahn M, Pino D, Vivas I, Leal M, Clerc K Functional trimming at the dry off period to prevent foot diseases in confined dairy cows at the tropical area. Rev Cient FCV-LUZ 2009; 19: 147-52.

[102] Weaver AD. Advance in Bovine Digital Diseases. Bov Pract Proceed 1993; 27: 23-7.

[103] Mitat VA. Antecedentes y perspectivas de la actividad bufalina en el trópico. Rev Tecnol Marcha 2011; 24: 121.

[104] López AR. Perspectivas de la crianza del búfalo de agua (Bubalus bubalis) en la Amazonía Ecuatoriana. Rev Amazónica: Cien Tec 2013; 2: 19-30.

[105] Arriaga-Jordán CM, Albarrán-Portillo $B$, Espinoza-Ortega A, García-Martínez A, Castelán-Ortega OA. On-farm comparison of feeding strategies based on forages for small- 
scale dairy production systems in the highlands of central Mexico. Exp Agric 2002; 38: 375-88. https://doi.org/10.1017/S0014479702000418

[106] Espinoza-Ortega A, Espinosa-Ayala E, Bastida-Lopez J, Castañeda-Martinez T, Arriaga-Jordán CM. Small-scale dairy farming in the highlands of central Mexico: Technical, economic and social aspects and their impact on poverty. Exp Agric 2007; 43: 241-56. https://doi.org/10.1017/S0014479706004613

[107] Tinoco-Magaña JC, Aguilar-Pérez CF, Delgado-León R, Magaña-Monforte JG, Ku-Vera JC, Herrera-Camacho J. Effects of energy supplementation on productivity of dualpurpose cows grazing in a silvopastoral system in the tropics. Trop Anim Health Prod 2012; 44: 1073-78. https://doi.org/10.1007/s11250-011-0042-8

[108] Mora-Medina $P$, Berdugo-Gutiérrez J, Mota-Rojas D, RuizBuitrago J, Nava AJ, Guerrero-Legarreta I. Behaviour and welfare of dairy buffaloes: pasture or confinement? J Buffalo Sci 2018; 7: 43-8.

https://doi.org/10.6000/1927-520X.2018.07.03.2

[109] Rojo RR, Vázquez AJF, Pérez HP, Mendoza MGD, Salem AZM, Albarrán BP, González RA, Hernández MJ, Rebollar RS, Cardoso JD, Dorantes CEJ, Gutiérrez C. Dual purpose cattle production in Mexico. Trop Anim Health Prod 2009; 41 715-21.

https://doi.org/10.1007/s11250-008-9249-8

[110] García-Martínez A, Albarrán-Portillo B, Avilés-Nova $F$. Dinámicas y tendencias de la ganadería doble propósito en el sur del Estado de México. Agrociencia 2015; 49: 125-39.

[111] Sabia E, Napolitano F, Claps S, De Rosa G, Braghieri A, Pacelli C., 2018. Dairy buffalo life cycle assessment as affected by heifer rearing system. J Cleaner Prod 192: 64755.

https://doi.org/10.1016/j.jclepro.2018.04.158

DOI: https://doi.org/10.6000/1927-520X.2020.09.12

(C) 2020 Bertoni et al.; Licensee Lifescience Global.

This is an open access article licensed under the terms of the Creative Commons Attribution Non-Commercial License (http://creativecommons.org/licenses/by-nc/3.0/) which permits unrestricted, non-commercial use, distribution and reproduction in any medium, provided the work is properly cited. 